\title{
A simple method for in vitro preparation of natural killer cells from cord blood
}

\author{
Yong Xu Mu${ }^{1 \dagger}$, Yu Xia Zhao ${ }^{2 \dagger}$, Bing Yao Li ${ }^{3}$, Hong Jing Bao ${ }^{2}$, Hui Jiang ${ }^{2}$, Xiao Lei Qi ${ }^{2}$, Li Yun Bai ${ }^{2}$, \\ Yun Hong Wang ${ }^{4,5}$, Zhi Jie Ma ${ }^{6 *}$ and Xiao Yun Wu ${ }^{4,5^{*}}$
}

\begin{abstract}
Background: Cord Blood (CB) has been considered a promising source of natural killer (NK) cells for cellular immunotherapy. However, it is difficult to expand the large numbers of highly pure NK cells from CB without cell sorting and feeder cells/multiple cytokines. In this study, we try to develop a simple, safe and economical method for ex vivo expansion and purification of NK cells from CB without cell sorting and feeder cells/multiple cytokines.

Results: The large numbers (mean: $1.59 \times 10^{10}$ ) of highly pure ( $\left.\geq 90 \%\right)$ NK cells from CB could be obtained through interleukin-2, group A streptococcus and zoledronate stimulation of mononuclear cells using the 21-day culture approach. When compared to resting NK cells, expanded NK cells were a higher expression of activating receptors CD16, NKG2D, NKp30, NKp44, NKp46 and activating markers CD62L and CD69, while the inhibitory receptors, CD158a and CD158b remained largely unchanged. In addition, these cells showed a higher concentration of IFN- $\gamma$, TNF- $a$ and GM-CSF secretion and cytotoxicity to K562 cells and acute myeloid leukemia targets than resting NK cells.

Conclusion: We develop a simple, safe and economical method to obtain high yield, purity, and functionality NK cells from CB without cell sorting and feeder cells/multiple cytokines.
\end{abstract}

Keywords: Cord blood, Natural killer cells, Expansion, Cytotoxicity, Immunotherapy

\section{Background}

Allogeneic natural killer (NK) cell infusion is promising for cancer immunotherapy because of the "missing self" hypothesis [1]. Cord blood (CB), serves as an immediate "off-the-shelf" source of NK cells, has been considered an attractive source of allogeneic NK cells for therapeutic infusion $[2,3]$. However, a major challenge of cell therapy with NK cells is to attain sufficient amount of highly pure cells $\left(>70 \%\right.$ pure, $\left.>1 \times 10^{9}\right)$ because of the low frequency and number $\left(<20 \%\right.$ pure, $\left.<1 \times 10^{8}\right)$ of NK cells in the CB $[3,4]$. To provide allogeneic NK cells with high yield, purity and functionality, some methods have been developed to purify and expand NK cells from CB ex vivo [5-10].

\footnotetext{
* Correspondence: 13811647091@163.com; stemcells@foxmail.com †Y Yong Xu Mu and Yu Xia Zhao contributed equally to this work. ${ }^{6}$ Department of Pharmacy, Beijing Friendship Hospital, Capital Medical University, Beijing, China

${ }^{4}$ Department of Technology, Stem Cell Medicine Engineering \& Technology Research Center of Inner Mongolia, Huhhot, Inner Mongolia, China Full list of author information is available at the end of the article
}

To date, most methods for in vitro preparation of NK cells from $\mathrm{CB}$ require to selecte NK cells with immuneselection techniques because of low frequency [11]. In order to avoid the limitations in low number and immature state of NK cells in $\mathrm{CB}$, ex vivo expansion and activation is necessary [12]. NK cells are generally isolated from $\mathrm{CB}$ through immunomagnetic beads selection protocols to enrich CD56-positive cells and/or deplete CD3-positive cells, and then cultured for functional expansion and activation using feeder cells, such as Epstein-Barr virus-transformed lymphoblastoid cell lines, mesenchymal stromal cells, gene-modified K562 cells expressing 4-1BB ligand and IL-15, and other irradiated tumor cell lines $[5,13]$. In addition, NK cells are originally generated from $\mathrm{CD}_{4} 4^{+}$hematopoietic stem cells (HSCs), some studies have described an alternative method to generate NK cells with high yield, purity and functionality from $\mathrm{CB}$-derived $\mathrm{CD} 34^{+} \mathrm{HSCs}$ under feeder cells-based conditions [10, 14-16]. Recently, a feeder cells-free method has been successfully performed for the generation of NK cells from CB-derived CD34 ${ }^{+}$ HSCs [7, 17]. However, it needs delicate culture

(c) The Author(s). 2019 Open Access This article is distributed under the terms of the Creative Commons Attribution 4.0 International License (http://creativecommons.org/licenses/by/4.0/), which permits unrestricted use, distribution, and 
regimens and multiple cytokine cocktails, which may lead to high cost-effectiveness. Generally, these methods require a complicated technology of cell sorting in an initial step, and it may increase the risk of cell trauma and contamination. Furthermore, the use of feeder cells or multiple cytokines during longer-term cultures would lead to NK cell apoptosis in vivo when optimum culturing conditions are eliminated after adoptive transfer [18]. In addition, these methods are also more costly because of complex operations and supplements.

Although several methods have been proposed to generate clinically relevant NK cell products (mean: $2 \times 10^{9}$ cells) with high purity (>90\%) from CB $[13,19]$, it is still difficult to obtain the sufficient numbers of highly pure NK cells from CB without cell sorting and feeder cells/ multiple cytokines [13]. Previously, we had found that zoledronate could increase enrichment, expansion and activation of NK cells from CB-derived mononuclear cells (MNCs) [20]. Some studies have reported that interleukin (IL)-2 expansion could recruit and activate key regulators involved in lytic immunological synapse formation of CB-derived NK cells, enabling effective cytotoxicity against killing of acute myeloid leukemia (AML) cells in vitro and in vivo [21, 22]. Group A streptococcus preparation, which is widely used as an immunopotentiator with considerable success in patients with malignant diseases, strongly augmented human NK cell activity in vivo as well as in vitro [23]. Therefore, we try to use develop a simple method with the capability of generating NK cells with high yield, purity and functionality from $\mathrm{CB}$ through using zoledronate, group A streptococcus and IL-2 stimulation of MNCs without cell sorting and feeder cells/multiple cytokines.

\section{Results}

\section{Preparation of NK cells from CB}

After the isolation process by Ficoll, an average of 5.02\% $\mathrm{CD} 6^{+} \mathrm{CD} 3^{-} \mathrm{NK}$ cells (range, 1.92 to $9.66 \%$ ) was obtained in MNCs, whereas $\mathrm{CD}^{-} 6^{-} \mathrm{CD}^{+} \mathrm{T}$ cells constituted $84.53 \%$ (range, 72.98 to $96.34 \%$ ). Expansion of $\mathrm{CD} 6^{+} \mathrm{CD}^{-} \mathrm{NK}$ cells was much higher compared with other types of cells, so NK cells dominated at the end of the culture, reaching on average $92.37 \%$ of the total cell populations (range: 88.91 to $96.37 \%$; Additional file 1) by day 21. The frequency of $\mathrm{CD}_{56}{ }^{+} \mathrm{CD}^{+}$NKT cells remained largely unchanged before and after culture (day 0: $1.05 \%$, day 21: $1.35 \%$ ), whereas the frequency of $\mathrm{CD} 56^{-} \mathrm{CD}^{+} \mathrm{T}$ cells declined, decreasing to an average of $4.56 \%$ (range: 1.30 to $9.63 \%$; Fig. 1a and b). By day 21, the total cell count had expanded on average 101-fold (range: 65-137-fold) and, among these, $\mathrm{CD}_{56}{ }^{+} \mathrm{CD} 3^{-} \mathrm{NK}$ cell population had expanded on average 1561-fold (range: $695-2387$-fold), reaching on average $1.59 \times 10^{10}$ (range: $0.84-2.23 \times 10^{9}$; Fig. $1 \mathrm{c}$ ). At this time point the expansion potential reached a plateau, thus the cells reached a quiescence phase when measured later on day 28. These data demonstrate that NK cells with high yield and purity could be expanded efficiently from CBderived MNCs ex vivo using the method described here.

\section{Surface expression of NK receptors and markers}

The expression of receptors and markers in expanded NK cells was assessed and compared to unexpanded NK cells. Among activating receptors, CD16 (day 0: $31.40 \%$, day 21: 66.91\%; $P<0.001$ ), NKp30 (day 0: $42.99 \%$, day 21 : $82.61 \%$; $P<0.001$ ), NKp44 (day 0: $11.72 \%$, day 21: $82.19 \%$; $P<$ 0.001), NKp46 (day 0: 6.68\%, day 21: 44.20\%; $P<0.001$ ) and NKG2D (day 0: 5.14\%, day 21: 72.20\%; $P<0.001$ ) significantly increased during the expansion while expression of the inhibitory receptors, CD158a (day 0:6.33\%, day 21: $6.68 \% ; P>0.05$ ) and CD158b (day 0: $9.40 \%$, day 21 : $10.91 \% ; P>0.05)$ remained largely unchanged during the culture period. Also, activation markers of the NK cells including CD62L (day 0: 21.66\%, day 21: 64.91\%; $P<0.001$ ) and CD69 (day 0: 7.47\%, day 21: $85.43 \%$; $P<0.001$ ) were increased on the surface of expanded NK cells (Fig. 2). These data demonstrate that NK cells are markedly activated after expansion.

\section{Cytokines production of expanded NK cells}

The secretion cytokines including granulocyte-macrophage colony-stimulating factor (GM-CSF), interferon-gamma (IFN- $\gamma$ ), and tumor necrosis factor-alpha (TNF- $\alpha$ ) were also assessed before and after culture. The very low level of IFN- $\gamma$ (mean: $5.21 \mathrm{pg} / \mathrm{mL}$, range: $1.37-8.45 \mathrm{pg} / \mathrm{mL}$ ), TNF- $\alpha$ (mean: $2.99 \mathrm{pg} / \mathrm{mL}$, range: $1.16-5.04 \mathrm{pg} / \mathrm{mL}$ ) and GM-CSF (mean: $6.95 \mathrm{pg} / \mathrm{mL}$, range: $4.38-9.81 \mathrm{pg} / \mathrm{mL}$ ) secretion was observed in unexpanded NK cells. Expanded NK cells exhibited significantly increased IFN- $\gamma$ (mean: $124.67 \mathrm{pg} / \mathrm{mL}$, range: $57.95-183.12 \mathrm{pg} / \mathrm{mL}$ ), TNF- $\alpha$ (mean: $853.94 \mathrm{pg} / \mathrm{mL}$, range: $479.67-1201.26 \mathrm{pg} / \mathrm{mL}$ ) and GM-CSF (mean: 81.67 $\mathrm{pg} / \mathrm{mL}$, range: $55.43-108.42 \mathrm{pg} / \mathrm{mL}$ ) secretion compared to unexpanded NK cells (all $P<0.001$, Fig. 3). These results demonstrate that the patterns of cytokine secretion are markedly increased after culture.

\section{Cytotoxicity of expanded NK cells}

The cytotoxicity levels of expanded vs. unexpanded NK cells against leukemia cell line (K562) and primary patient AML blasts were evaluated. The unexpanded NK cells were poor cytotoxicity against K562 cells (range: 1.91$5.86 \%$ ) and primary patient AML blasts (range: 1.24$2.89 \%$ ) at a variety of E:T ratios, but the expanded NK cells showed high levels of cytotoxicity against K562 (range: 52.63-82.18\%) and AML targets (range: 15.28-24.07\%). NK cells expanded in culture consistently exhibited a high level of cytotoxicity against K562 and AML targets 


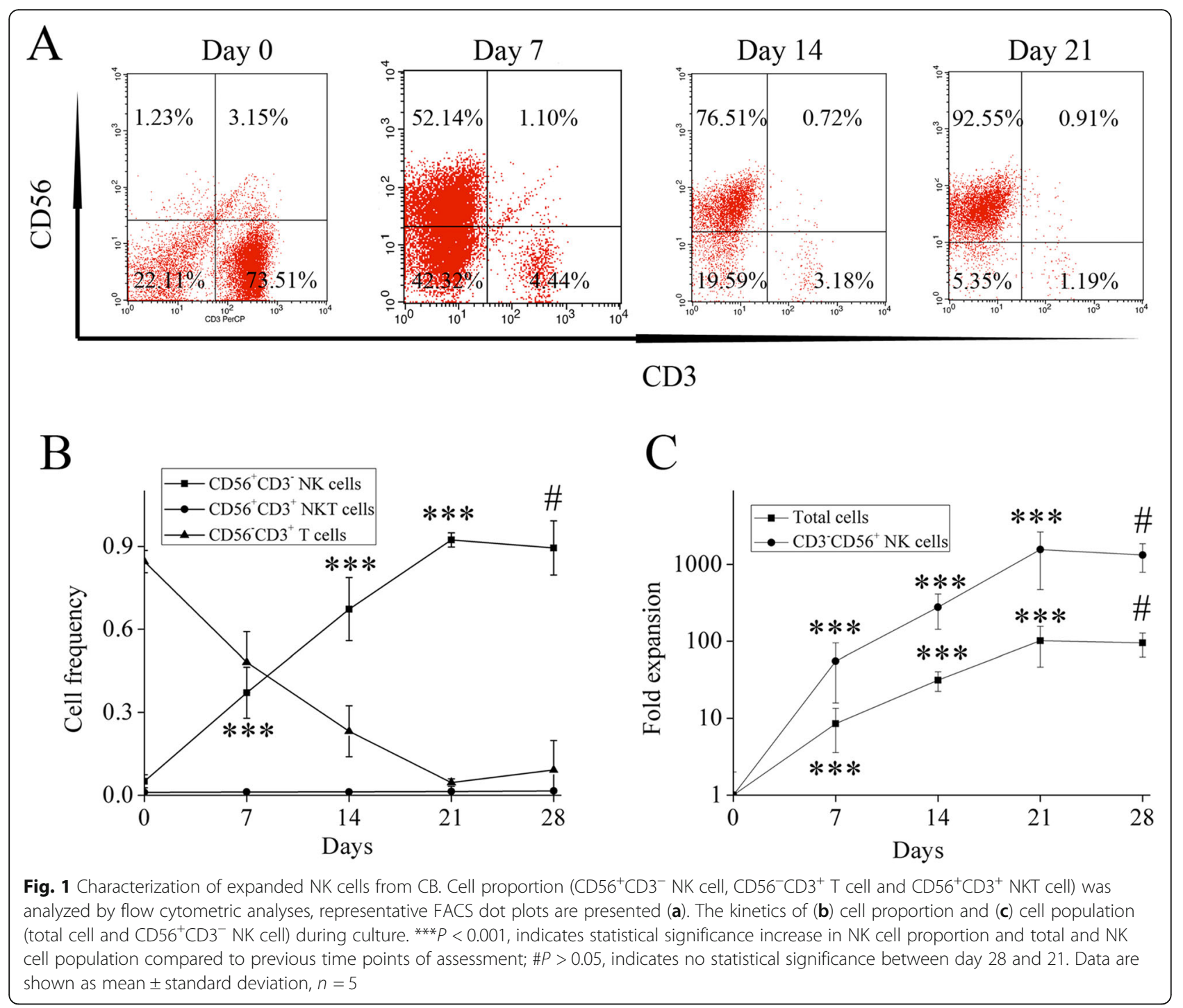

compared to unexpanded NK cells at a wide range of E:T ratios (all $P<0.001$, Fig. 4). These results show that cytotoxicity of NK cells are markedly elevated after expansion.

\section{Discussion}

In this study, we develop a simple and economical method for in vitro preparation of NK cells through IL2, group A streptococcus and zoledronate stimulation of CB-derived MNCs. it is a practically advantageous method that does not need cell sorting and feeder cells/ multiple cytokines, which could lead to reduction in cost. Furthermore, IL-2, streptococcus A group and zoledronate have also been approved for human use, which could increase the safety. In addition, this simple method is more easily standardized and exportability. To our knowledge, this is the first report of a simple method for in vitro preparation of NK cells from $\mathrm{CB}$ without cell sorting and feeder cells/multiple cytokines.
Using this method, a mean number of $1.59 \times 10^{10} \mathrm{NK}$ cells with an average purity of $92.37 \%$ are generated after 21 days of culture. Previously, we found that zoledronate had a favorable effect on expansion of NK cells from CB-derived MNCs [20]. Furthermore, the addition of group A streptococcus induced a higher increase in the expansion fold (1561 vs. 1286) of NK cells, showing that both have the synergism. A study has reported a multiple cytokines-based delicate culture method for up to 6 weeks to generate therapeutic NK cell products (mean: $2 \times 10^{9}$ cells) with high purity (>90\%) from CB-derived CD34 ${ }^{+}$HSCs [9]. Compared with this method, our method yields much higher number (8-times) of NK cells with less time. We hypothesize that this is related to very low proportion of $\mathrm{CD} 34^{+} \mathrm{HSCs}$ in $\mathrm{CB}$ and cumbersome procedures including HSCs expansion and NK cell differentiation and expansion. Other group has reported that a feeder cell-based NK cultivation method is 


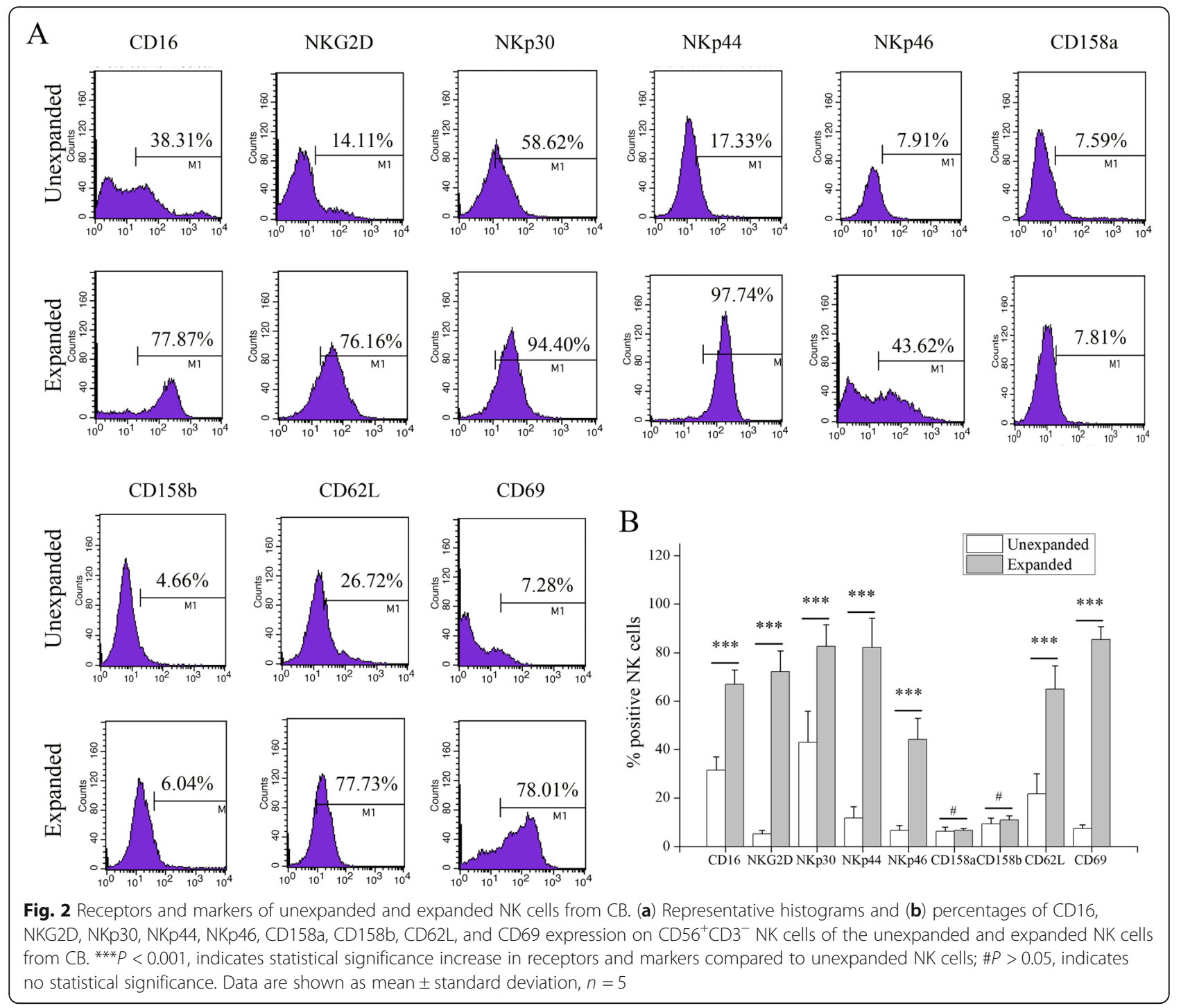

established with the capability of generating a clinically relevant dose (mean: $1.2 \times 10^{9}$ cells) with a purity of $>$ $80 \%$ of CB-derived NK cells [6]. Compared with this method, our method also yields much higher number (15-times) of NK cells with the same time. A possible explanation might be that accessory cells such as monocytes in CB-derived MNCs can support NK cell expansion [24]. Therefore, A large amount of NK cells generated in vitro by our method can be, allowed for multiple infusions of NK cells.

Purity, as one of crucial release criteria for NK cellbased therapies, has not yet been standardized, but $>90 \%$ $\mathrm{CD}_{56}{ }^{+} \mathrm{CD} 3^{-}$for allogenic NK cells have been suggested in recently published study $[9,25]$. Previously, we found that zoledronate had a favorable effect on enrichment of NK cells from CB-derived MNCs [20]. Furthermore, the addition of group A streptococcus induced a greater increase in the frequency $(92.37 \%$ vs. $80.46 \%)$ of NK cells, showing that both have the synergism. The purity of NK cells produced by our method is comparable to cytokinebased culture method (>90\%) [9], but higher compared to feeder cell-based method (> 80\%) [6].

Another crucial obstacle is the immaturity state of NK cells in CB [3]. It has been known that NK cell cytotoxicity is regulated by the complex balance between activating and inhibitory receptors. NK cells expended by our method exhibit high expression level of activating receptors CD16, NKG2D, NKp30, NKp44 and NKp46, but unchanged expression level of inhibitory receptors CD158a and CD158b compared with unexpended NK cells. This leads to high-level expression of activating markers CD62L and CD69, showing that NK cells expanded in this study have activated a cellular mechanism controlling effector function. A recent study also reported no changes in expression of CD158a and CD158b by CB-derived NK cells after incubation with 


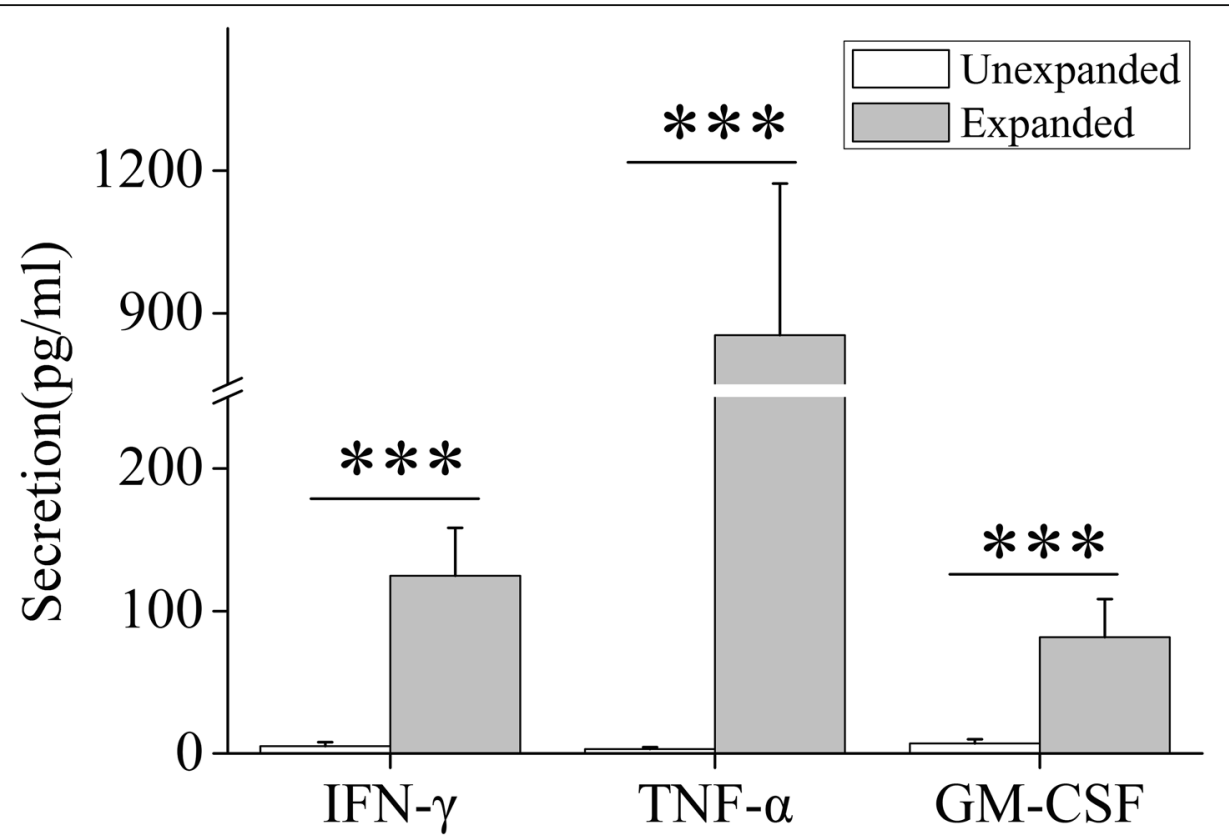

Fig. 3 Cytokine production of unexpanded and expanded NK cells from CB. ${ }^{* *} P<0.001$, indicates statistical significance increase in cytokine production compared to unexpanded NK cells. Data are shown as mean \pm standard deviation, $n=5$

IL-2, IL-12 or IL-18 [26]. This confirms that killer cell Ig-like receptor acquisition does not require group A streptococcus and zoledronate activation.

Previous studies have shown that IL-2-activated NK cells from $\mathrm{CB}$ exhibited significantly increased frequency of IFN- $\gamma$ and TNF- $\alpha$ secretion compared with unexpended NK cells $[21,26]$. In previous study, we showed that zoledronate increased IFN- $\gamma$, TNF- $\alpha$ and GM-CSF secretion by IL-2-activated NK cells from CB [20]. Early study showed that group A streptococcus stimulated human lymphocytes to produce IFN (both a- and $\gamma$-types) and IL-2 and that both factors were primarily responsible for the NK augmentation by group A streptococcus [23]. It has been previously shown that cytokines including IFN- $\gamma$, TNF- $\alpha$ and GM-CSF play key roles in NK cell functions [27]. To evaluate the impact of IL-2, zoledronate and group A streptococcus on the secretion of cytokines by $\mathrm{CB}$ NK cells, cytokines secretion was measured in the supernatants of unexpended and expanded NK cell cultures. The result shows that NK cells expanded by our method can produce robust inflammatory cytokine IFN- $\gamma$, TNF- $\alpha$ and GM-CSF. We further

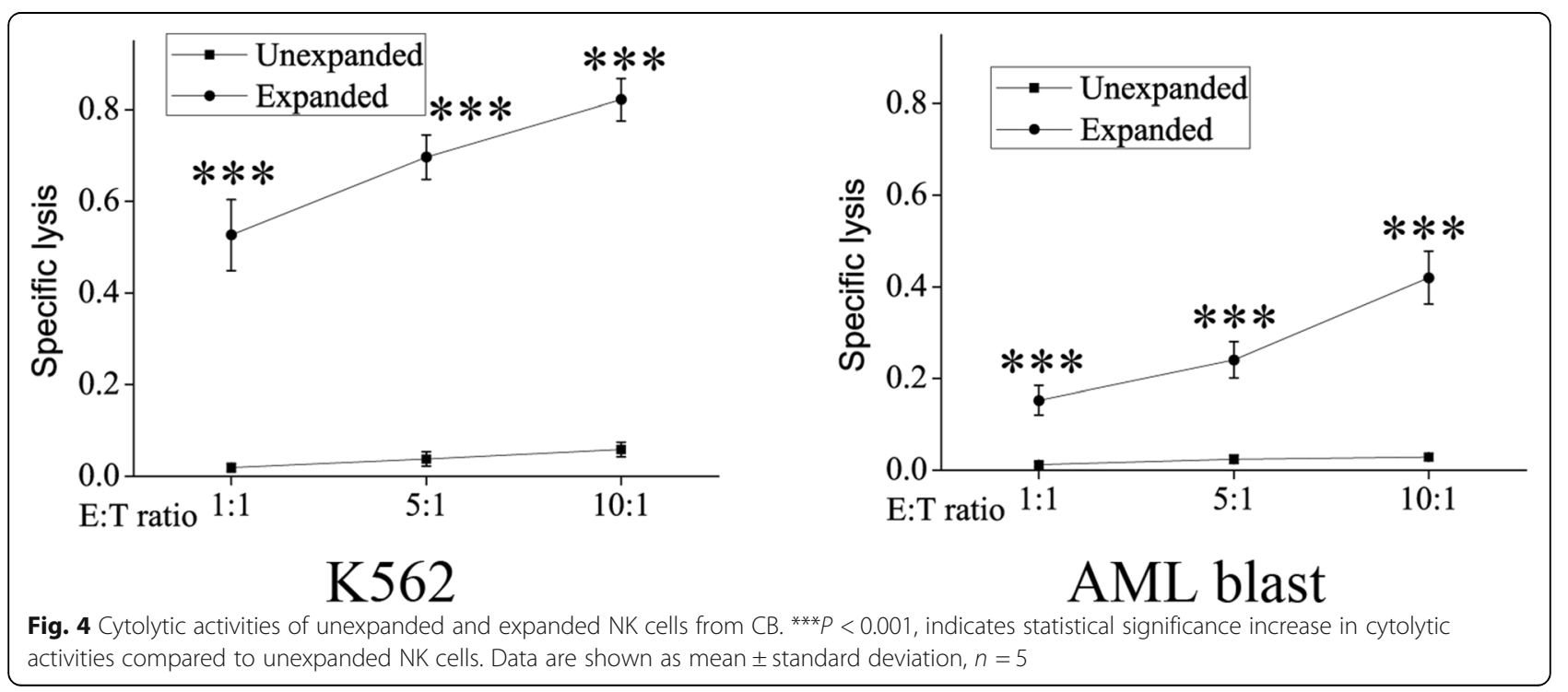


investigate that NK cells expanded by our method can induce lytic function against $\mathrm{K} 562$ and primary AML targets compared with unexpended NK cells, showing that ex vivo generated NK cells from CB could contribute greatly to the elimination of tumor during adoptive NK cell immunotherapy. These results are comparable to data from zoledronate only, showing no synergy between them. This might be related to MNCs rather than purified NK cells. However, in vivo functional studies are needed to explore in the next study.

\section{Conclusion}

We have developed a simple, safe and economical method to obtain high yield, purity, and functionality NK cells from CB through IL-2, streptococcus A group and zoledronate stimulation of MNCs without cell sorting and feeder cells/ multiple cytokines. Adoptive transfer of NK cells generated from CB by this method may therefore provide a promising new paradigm for the treatment of patients with AML and other hematological malignancies. This simple method satisfies the standards for in vitro preparation of NK cells as a potential therapeutic product, is more accessible for clinical practice, and may hold valuable potential for adoptive cellular immunotherapy for hematological malignancies like AML.

\section{Methods}

\section{NK cells preparation}

All frozen $C B$ samples were drawn from the Shandong Cord Blood Bank. MNCs were isolated from $\mathrm{CB}$ using Ficoll-Hypaque density gradient centrifugation. For activation, MNCs were cultured for 3 days in T175 flasks at $2 \times 10^{6}$ cells $/ \mathrm{mL}$ in AIM-V serum free media (Life Technologies) supplemented with $2000 \mathrm{IU}$ IL-2/mL (Four Rings Biopharma, China), $0.01 \mathrm{KE} / \mathrm{mL}$ group A streptococcus (Lu Ya Pharma, China) and $5 \mu \mathrm{M}$ zoledronate (Novartis Pharma). For expansion, the fresh medium containing $2000 \mathrm{IU} \mathrm{IL}-2 / \mathrm{mL}$ was added every 2 to 3 days for 21 days. An outline of the preparation protocol is summarized in Fig. 5 .

\section{Expansion kinetics assessment}

Total cell counts were determined by trypan blue staining on days $0,7,14,21$ and 28. Absolute cell numbers were calculated by multiplying the total cell count by the percentage of each cell type determined by flow cytometry. Cell expansion efficiency was expressed as "fold expansion" which was determined by dividing the number of total cells or absolute NK cells on days 7, 14, 21 and 28 by the number on day 0 .

\section{Flow Cytometr}

The cells were labeled with fluorochrome-conjugated mouse mAbs against human cluster of differentiation CD3, CD56, CD16, CD158a, CD158b and NKG2D (BD Biosciences); NKp30, NKp44 and NKp46 (Beckman Coulter); CD69, CD62L (Miltenyi Biotec). Isotypematched antibodies were used as controls. Flow cytometry analysis was performed using a MACSQuant Analyzer (Miltenyi Biotec). Data were analyzed with MACSQuantify Software.

\section{Cytokines release assay}

The cell culture supernatants were collected, the level of cytokines including IFN- $\gamma$, TNF- $\alpha$ and GM-CSF in supernatants was analyzed using enzyme-linked immunosorbent assay kits (eBioscience, Inc) according to the manufacturer's instructions.

\section{Cytotoxicity assay}

The cytotoxicity of NK cells was analyzed using the standard 4-h ${ }^{51} \mathrm{Cr}$ release assay. The NK-sensitive leukemia cell line (K562) and primary AML blasts (target) were labeled with ${ }^{51} \mathrm{Cr}$ sodium chromate and incubated with NK cells (effector) at different target-toeffector (E:T) ratios (1:1, 5:1, and 10:1) in U-bottomed 96-well plates. ${ }^{51} \mathrm{Cr}$-release was determined in the supernatant after co-culture for $4 \mathrm{~h}$. The maximum release was measured by treating target cells with $2 \%$ Triton X100 and spontaneous release was determined with medium alone. The specific lysis was calculated according to the formula: (experimental release - spontaneous release) / (maximum release - spontaneous release).

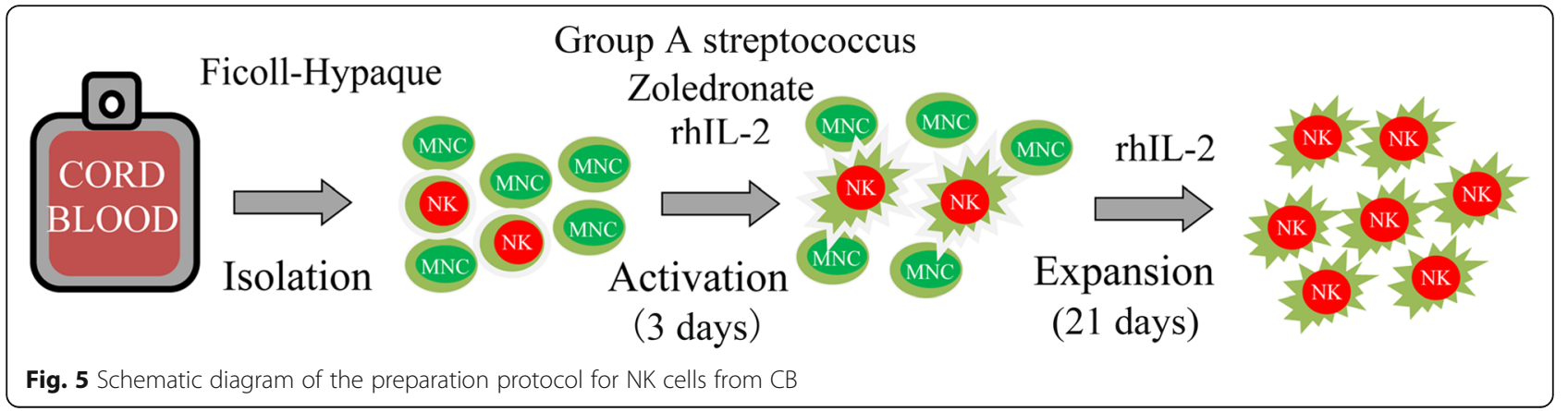




\section{Statistical analysis}

Data are presented as the mean \pm standard deviation. Statistical difference was determined using a student's $t$ test when comparing two groups, or a one-way ANOVA analysis when more than two groups (Graphpad Prism 5.0). $P<0.05$ was considered significant.

\section{Supplementary information}

Supplementary information accompanies this paper at https://doi.org/10. 1186/s12896-019-0564-0.

Additional file 1: Figure S1. FACS analysis gating strategy for NK cells expanded on day 21 .

\begin{abstract}
Abbreviations
AML: Acute myeloid leukemia; CB: Cord blood; E:T: Effector-to-target; GMCSF: Granulocyte-macrophage colony-stimulating factor;

HSCs: Hematopoietic stem cells; IFN-ץ: Interferon-gamma; IL: Interleukin; MNCs: Mononuclear cells; NK: Natural killer; TNF-a: Tumor necrosis factoralpha
\end{abstract}

\section{Acknowledgements}

We acknowledged the kind support from Department of Technology, Beijing.

JingMeng Stem Cell Technology. Co. Ltd., Beijing, China.

\section{Authors' contributions}

All authors participated in the design, interpretation of the results, and review of the manuscript; YXM and XYW were involved in the experimentation, and wrote the manuscript; $Y X Z, H J B$ and BYL were involved in the analysis of the data. $H J, X L Q$ and LYB generated the figures and contributed to editing the manuscript, the study was conceived by YHW and ZGL who also edited the manuscript. All authors read and approved the final manuscript.

\section{Funding}

This work was supported by National Natural Science Foundation of China (No. 81860157) and Natural Science Foundation of Inner Mongolia (No. 2017MS0314)

\section{Availability of data and materials}

The datasets used and analyzed during the current study are available from the corresponding author on reasonable request.

\section{Ethics approval and consent to participate}

All frozen CB samples were obtained with prior consent and ethical committee approval from the Shandong Cord Blood Bank. The study had full ethical approval from the institutional ethics committee of Beijing Friendship Hospital.

\section{Consent for publication}

Not applicable.

\section{Competing interests}

A patent application for the composition for expanding NK cells and the use of them has been filed with Xiao Yun Wu as a first inventor. Other authors declare that they have no conflict of interest.

\section{Author details}

${ }^{1}$ Interventional Department, the First Affiliated Hospital of Baotou Medical College, Inner Mongolia University of Science and Technology, Baotou, Inner Mongolia, China. ²Department of Blood, the People's Hospital of Xing'an League, Xing'an League, Inner Mongolia, China. ${ }^{3}$ Department of Medicine, Chifeng Cancer Hospital, Chifeng, Inner Mongolia, China. ${ }^{4}$ Department of Technology, Stem Cell Medicine Engineering \& Technology Research Center of Inner Mongolia, Huhhot, Inner Mongolia, China. ${ }^{5}$ Department of Research and Development, Beijing Jingmeng Stem Cell Technology CO., LTD, Beijing, China. ${ }^{6}$ Department of Pharmacy, Beijing Friendship Hospital, Capital Medical University, Beijing, China.
Received: 12 September 2018 Accepted: 27 September 2019

Published online: 21 November 2019

\section{References}

1. Lim O, Jung MY, Hwang YK, Shin EC. Present and future of allogeneic natural killer cell therapy. Front Immunol. 2015;6:286.

2. Shaim H, Yvon E. Cord blood: a promising source of allogeneic natural killer cells for immunotherapy. Cytotherapy. 2015;17(1):1-2.

3. Mehta RS, Shpall EJ, Rezvani K. Cord blood as a source of natural killer cells. Front Med. 2015;2:93.

4. Klingemann $\mathrm{H}$. Challenges of cancer therapy with natural killer cells. Cytotherapy. 2015;17(3):245-9.

5. Hosseini E, Ghasemzadeh M, Kamalizad M, Schwarer AP. Ex vivo expansion of CD3depleted cord blood-MNCs in the presence of bone marrow stromal cells; an appropriate strategy to provide functional NK cells applicable for cellular therapy. Stem Cell Res. 2017;19:148-55.

6. Kang L, Voskinarian-Berse V, Law E, Reddin T, Bhatia M, Hariri A, Ning Y, Dong D, Maguire T, Yarmush $M$, et al. Characterization and ex vivo expansion of human placenta-derived natural killer cells for Cancer immunotherapy. Front Immunol. 2013;4:101.

7. Cany J, van der Waart AB, Tordoir M, Franssen GM, Hangalapura BN, de Vries J, Boerman O, Schaap N, van der Voort R, Spanholtz J, et al. Natural killer cells generated from cord blood hematopoietic progenitor cells efficiently target bone marrow-residing human leukemia cells in NOD/SCID/IL2Rg(null) mice. PLoS One. 2013;8(6):e64384.

8. Dezell SA, Ahn YO, Spanholtz J, Wang H, Weeres M, Jackson S, Cooley S, Dolstra H, Miller JS, Verneris MR. Natural killer cell differentiation from hematopoietic stem cells: a comparative analysis of heparin- and stromal cell-supported methods. Biol Blood Marrow Transplant. 2012;18(4):536-45.

9. Spanholtz J, Preijers F, Tordoir M, Trilsbeek C, Paardekooper J, de Witte T, Schaap N, Dolstra H. Clinical-grade generation of active NK cells from cord blood hematopoietic progenitor cells for immunotherapy using a closedsystem culture process. PLoS One. 2011;6(6):e20740.

10. Frias AM, Porada CD, Crapnell KB, Cabral JM, Zanjani ED, Almeida-Porada G. Generation of functional natural killer and dendritic cells in a human stromal-based serum-free culture system designed for cord blood expansion. Exp Hematol. 2008;36(1):61-8.

11. Becker PS, Suck G, Nowakowska P, Ullrich E, Seifried E, Bader P, Tonn T, Seid C. Selection and expansion of natural killer cells for NK cell-based immunotherapy. Cancer Immunol Immunother. 2016;65(4):477-84.

12. Lapteva N, Szmania SM, van Rhee F, Rooney CM. Clinical grade purification and expansion of natural killer cells. Crit Rev Oncog. 2014;19(1-2):121-32.

13. Chabannon C, Mfarrej B, Guia S, Ugolini S, Devillier R, Blaise D, Vivier E, Calmels B. Manufacturing natural killer cells as medicinal products. Front Immunol. 2016;7:504

14. Pinho MJ, Punzel M, Sousa M, Barros A. Ex vivo differentiation of natural killer cells from human umbilical cord blood CD34+ progenitor cells. Cell Commun Adhes. 2011;18(3):45-55.

15. Boissel L, Tuncer HH, Betancur M, Wolfberg A, Klingemann H. Umbilical cord mesenchymal stem cells increase expansion of cord blood natural killer cells. Biol Blood Marrow Transplant. 2008;14(9):1031-8.

16. Kao IT, Yao CL, Kong ZL, Wu ML, Chuang TL, Hwang SM. Generation of natural killer cells from serum-free, expanded human umbilical cord blood CD34+ cells. Stem Cells Dev. 2007;16(6):1043-51.

17. Domogala A, Blundell M, Thrasher A, Lowdell MW, Madrigal JA, Saudemont A. Natural killer cells differentiated in vitro from cord blood CD34+ cells are more advantageous for use as an immunotherapy than peripheral blood and cord blood natural killer cells. Cytotherapy. 2017;19(6):710-20.

18. Childs RW, Berg M. Bringing natural killer cells to the clinic: ex vivo manipulation. Hematology Am Soc Hematol Educ Program. 2013;2013:234-46.

19. Koehl U, Kalberer C, Spanholtz J, Lee DA, Miller JS, Cooley S, Lowdell M, Uharek L, Klingemann H, Curti A, et al. Advances in clinical NK cell studies: donor selection, manufacturing and quality control. Oncoimmunology. 2016;5(4):e1115178

20. Ma Z, Wang Y, Kang H, Wu X. Zoledronate increases enrichment, activation and expansion of natural killer cells from umbilical cord blood. Hum Cell. 2018;31:310-2.

21. Xing D, Ramsay AG, Gribben JG, Decker WK, Burks JK, Munsell M, Li S, Robinson SN, Yang H, Steiner D, et al. Cord blood natural killer cells exhibit impaired lytic immunological synapse formation that is reversed with IL-2 exvivo expansion. J Immunother. 2010;33(7):684-96. 
22. Khaziri N, Mohammadi M, Aliyari Z, Soleimani Rad J, Tayefi Nasrabadi H, Nozad Charoudeh H. Cord blood mononuclear cells have a potential to produce NK cells using IL2Rg cytokines. Adv Pharm Bull. 2016;6(1):5-8.

23. Wakasugi H, Kasahara T, Minato N, Hamuro J, Miyata M, Morioka Y. In vitro potentiation of human natural killer cell activity by a streptococcal preparation, OK-432: interferon and interleukin-2 participation in the stimulation with OK-432. J Natl Cancer Inst. 1982;69(4):807-12.

24. Koehl U, Brehm C, Huenecke S, Zimmermann SY, Kloess S, Bremm M, Ullrich E, Soerensen J, Quaiser A, Erben S, et al. Clinical grade purification and expansion of NK cell products for an optimized manufacturing protocol. Front Oncol. 2013;3:118.

25. Berg M, Childs R. Ex-vivo expansion of NK cells: what is the priority--high yield or high purity? Cytotherapy. 2010;12(8):969-70.

26. Alnabhan R, Madrigal A, Saudemont A. Differential activation of cord blood and peripheral blood natural killer cells by cytokines. Cytotherapy. 2015; 17(1):73-85.

27. Yoon SR, Kim TD, Choi I. Understanding of molecular mechanisms in natural killer cell therapy. Exp Mol Med. 2015;47:e141.

\section{Publisher's Note}

Springer Nature remains neutral with regard to jurisdictional claims in published maps and institutional affiliations.

Ready to submit your research? Choose BMC and benefit from:

- fast, convenient online submission

- thorough peer review by experienced researchers in your field

- rapid publication on acceptance

- support for research data, including large and complex data types

- gold Open Access which fosters wider collaboration and increased citations

- maximum visibility for your research: over $100 \mathrm{M}$ website views per year

At BMC, research is always in progress.

Learn more biomedcentral.com/submissions 